\begin{tabular}{|c|c|c|}
\hline \multirow[b]{2}{*}{$\mathrm{TN}$} & $\begin{array}{l}\text { International Journal of Current Research in } \\
\text { Biosciences and Plant Biology }\end{array}$ & $=$ \\
\hline & Volume $5 \bullet$ Number 8 (August-2018) • ISSN: 2349-8080 (Online) & siles \\
\hline $\begin{array}{l}\text { EXCELLENT } \\
\text { PUBLISHERS }\end{array}$ & Journal homepage: www.ijcrbp.com & 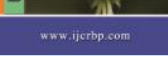 \\
\hline
\end{tabular}

Original Research Article

doi: $\underline{\text { https://doi.org/10.20546/ijcrbp.2018.508.008 }}$

\title{
Effect of Sulphur Sources on Growth and Yield of Sesamum indicum L. cv. VRI-1
}

\author{
N. Senthilkumar* \\ Department of Soil Science and Agricultural Chemistry, Faculty of Agriculture, Annamalai University, \\ Annamalai Nagar-608 002, Tamil Nadu, India
}

${ }^{*}$ Corresponding author.

\begin{tabular}{|c|c|}
\hline Article Info & ABSTRACT \\
\hline & \multirow{9}{*}{ 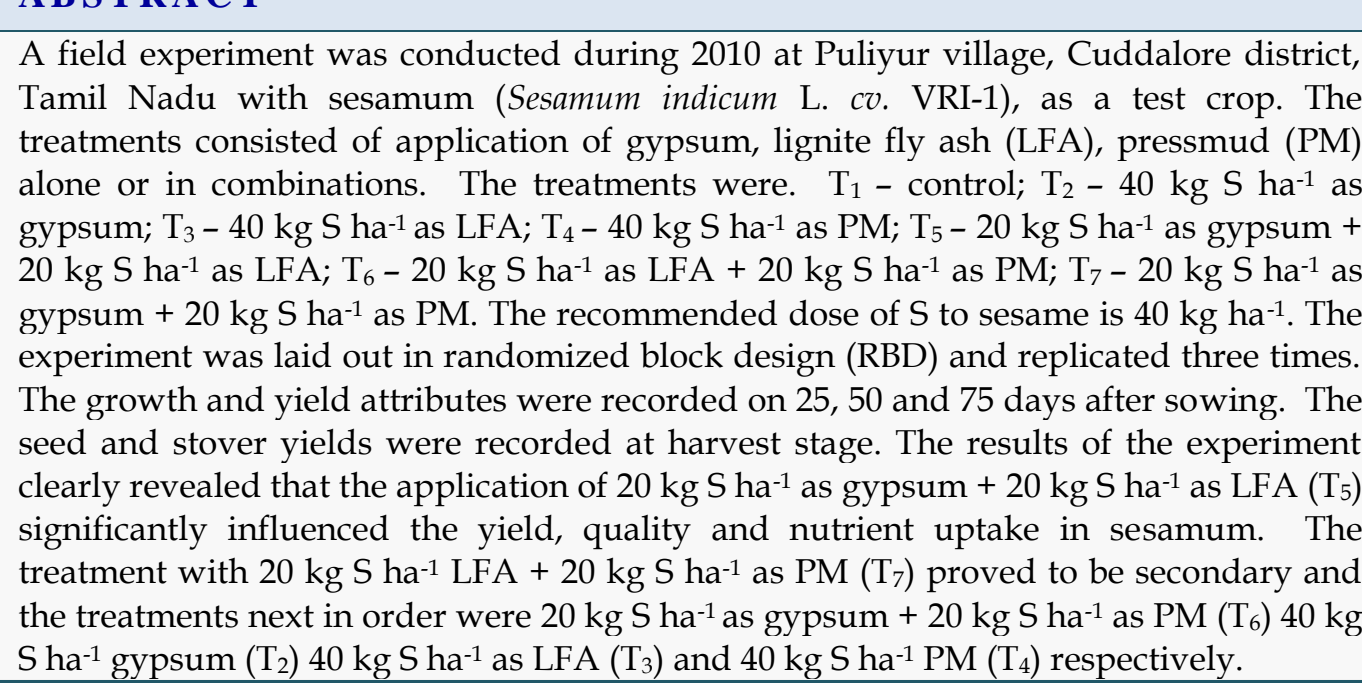 } \\
\hline & \\
\hline & \\
\hline Keywords & \\
\hline Gypsum & \\
\hline Liq & \\
\hline Pres & \\
\hline Sesamum & \\
\hline Yield & \\
\hline
\end{tabular}

\section{Introduction}

Oil seeds, the second largest agricultural commodity after cereals in India, play a significant role in India's agrarian economy, sharing 14\% of the gross cropped area and accounting for nearly $1.5 \%$ of the gross national product and $8 \%$ of the value of all agricultural products. Sesamum
(Sesamum indicum L.) the 'queen of oil seeds' is one of the most ancient oil seed known and used by man. Africa is considered to be the primary centre of origin. India is the secondary centre of origin and another secondary centre is Japan. Sesame is the second most important oil seed crop next to groundnut due to the presence of potent antioxidants. The area under sesamum in India was 
2.01 million $\mathrm{ha}^{-1}$ with the production of 0.86 million tonnes having productivity of $304 \mathrm{~kg} \mathrm{ha}^{-1}$ during 2009-2010 (Hegde and Sudhakarababu, 2011).

In Tamil Nadu, it is being cultivated an area of 1.04 lakh hectares with the production of 0.65 lakh tonnes year ${ }^{-1}$ with average productivity of $589 \mathrm{~kg}$ ha $^{-1}$ (Krishnaprabu, 2006).

The deficiency of $\mathrm{S}$ is being reported from more than 70 countries all over world including India. Intensive cropping with high yielding varieties as a great endeavour for boosting food production and shift into the use of $S$ free high analysis fertilizers along with depletion of $\mathrm{S}$ from soil because of nonreplenishment, are some of the important reasons for increasing $\mathrm{S}$ deficiencies in the soils (Kalpana, 2005).

Sulphur is the best known for its role in the formation of amino acid, synthesis of proteins, vitamins and chlorophyll and improving the oil content. Its deficiency in Indian soils and crops are widespread and still increasing. Hence, it becomes obligatory to take care of the $S$ needs of oil seeds through external addition of S (Maragatham et al., 2006).

In India, approximately 260 million tonnes of coal is consumed per annum by 82 utility thermal power plants (TPPs). In India (2003-04), it constituent nearly $70 \%$ of the total power generation, which in turn, produced 112 million tonnes of fly ash per annum. The annual generation of fly ash is projected to exceed 175 million tonnes per annum by 2012 (considering the plants to double the powder generation over next 10 years). This large volume of fly ash occupied large area of land and poses threat to environment. As such, there is an urgent and imperative need to adapt technologies for gainful utilization and safe management of fly ashes on sustainable basis. Next, the input cost incurred to gingely crop towards the mineral nutrition is very high. So, we have to think of cheaper and easily available carrier materials such as lignite fly ash, gypsum and pressmud.
In India, vast potentials of more than 2.8 million tonnes of pressmud cake is available (PM) (Ramalingaswamy et al., 1996). Pressmud is an important by product of the sugar industry contains considerable amount of calcium, organic matter and phosphorus along with nitrogen, potassium and minor nutrients in varying quantities (Muthuraju et al., 2005). The composition of pressmud varies depending in the maturity of cane milling percentage and method of clarification employed. It has generally been used as soil conditioner, soil amelioration and source of nutrients for crop growth. Pressmud being a good source of plant nutrients is reported to have $2.4 \% \mathrm{~N}, 1.47 \% \mathrm{P}$ and $3.1 \%$ of $\mathrm{K}$ under sulphitation process. So it can also be used as the source of nutrient in combination with inorganic fertilizers.

The chemical fertilizers especially sulphur fertilizers are imported from other countries and thereby, fertilizer cost in very high. In view of cost escalation of inorganic fertilizers there is a need to utilize organic wastes and industrial wastes. In a tropical country like India, addition of organic wastes, crop residues and industrial wastes to soil is crucial for maintaining the soil fertility and successful crop production. In view of the above facts, the present investigation was undertaken by carrying out a field experiment.

\section{Materials and methods}

The effect of gypsum, lignite fly ash and pressmud as sources of sulphur, growth and yield attributes and yield of Sesamum indicum L. cv. VRI-1. A field experiment was carried out at farmers holding in Puliyur village, Cuddalore district, Tamil Nadu. The treatments consisted of application of gypsum, lignite fly ash (LFA), pressmud (PM) alone or in combinations. The treatments were. $\mathrm{T}_{1}-$ control; $\mathrm{T}_{2}-40 \mathrm{~kg} \mathrm{~S} \mathrm{ha}^{-1}$ as gypsum; $\mathrm{T}_{3}-40 \mathrm{~kg} \mathrm{~S} \mathrm{ha}^{-1}$ as LFA; $\mathrm{T}_{4}-40 \mathrm{~kg} \mathrm{~S}^{-1}$ as PM; $\mathrm{T}_{5}-20 \mathrm{~kg} \mathrm{~S}^{-1}$ as

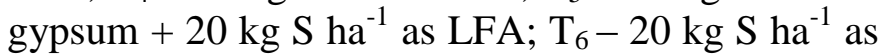
$\mathrm{LFA}+20 \mathrm{~kg} \mathrm{Sha}^{-1}$ as PM; $\mathrm{T}_{7}-20 \mathrm{~kg} \mathrm{~S} \mathrm{ha}^{-1}$ as gypsum $+20 \mathrm{~kg} \mathrm{~S}^{-1}$ as PM. The recommended dose of $\mathrm{S}$ to sesamum is $40 \mathrm{~kg} \mathrm{ha}^{-1}$. The experiment 
was laid out in randomized block design (RBD) and replicated three times. The growth and yield attributes were recorded on 25, 50 and 75 days after sowing. The seed and stover yields were recorded at harvest stage.

The soil of Puliyur village was found to contain $63.25,24.20$ and $12.50 \%$ sand, clay and silt respectively and come under the textural class sandy clay loam. The bulk density, particle density, pore space, $\mathrm{pH}$, electrical conductivity and cation exchange capacity of the soil were $1.57,2.22 \mathrm{mg} \mathrm{m}^{-}$ ${ }^{3}, 29.20 \%$ and $6.40,0.156 \mathrm{dS} \mathrm{m} \mathrm{m}^{-1}$ and $6.50 \mathrm{C} \mathrm{mol}$ $\left(\mathrm{p}^{+}\right) \mathrm{kg}^{-1}$ respectively. The organic carbon content of soil was $0.198 \mathrm{~g} \mathrm{~kg}^{-1}$. The available $\mathrm{N}, \mathrm{P}$ and $\mathrm{K}$ content of soil was $190.6,14.2$ and $110.3 \mathrm{~kg} \mathrm{ha}^{-1}$ respectively. The available sulphur content was $8.25 \mathrm{mg} \mathrm{kg}^{-1}$. The exchangeable calcium, magnesium and potassium content were 2.36, 1.56, $0.25 \mathrm{C} \mathrm{mol}\left(\mathrm{p}^{+}\right) \mathrm{kg}^{-1}$ by respectively.

\section{Results and discussion}

\section{Growth of Sesamum indicum L. cv. VRI-1}

Among the different treatments tried, application of $20 \mathrm{~kg} \mathrm{~S} \mathrm{ha}{ }^{-1}$ gypsum $+20 \mathrm{~kg} \mathrm{~S}^{-1}$ as $\operatorname{LFA}\left(\mathrm{T}_{5}\right)$ through gypsum recorded the maximum plant height and number of branches and this was found to be followed by $20 \mathrm{~kg} \mathrm{Sha}^{-1}$ as LFA $+20 \mathrm{~kg} \mathrm{~S}^{-}$ ${ }^{1}$ as $\mathrm{PM}\left(\mathrm{T}_{7}\right)$ and $20 \mathrm{~kg} \mathrm{~S} \mathrm{ha}^{-1}$ as gypsum $+20 \mathrm{~kg} \mathrm{~S}$ ha $^{-1}$ as pressmud $\left(\mathrm{T}_{6}\right)$ might be the optimum dose to the next higher dose of $40 \mathrm{~kg} \mathrm{Sha}^{-1}$ as gypsum $\left(\mathrm{T}_{2}\right)$ to sesamum (Table 1). This increase in plant height with gypsum might be attributed to supply of sulphur in move readily available form and which in turn powered way for better uptake of sulphur. This ultimately leads to increment in plant height (Vishwakarma et al., 1998). The increased plant height with LFA might be due to improvement in availability of most of the nutrients along with $\mathrm{S}$ by imparting a favourable environment in soil which helped the elements to be moved in the available form. This might have influenced to root formation and increased the plant height. Similar results were reported by Kuchanwar et al. (1997).

\section{Yield of Sesamum indicum L.cv. VRI-1}

Application of gypsum and lignite fly ash significantly increased the seed and stover yield of sesamum. Among the different treatments tried, the application of $20 \mathrm{~kg} \mathrm{~S}^{-1}$ gypsum $+20 \mathrm{~kg} \mathrm{~S}^{-1}$ LFA recorded the maximum seed and stover yield of sesamum (Table 2). The response to gypsum and LFA might be ascribed to adequate supply of $\mathrm{S}$ and $\mathrm{Ca}$ nutrients that could have resulted in higher production of photosynthates and their translocation to sink. This might have increased the resulted into higher seed and stover yield. Similar trend of results were obtained by Muzaffer Sofi et al. (2004) and Poonkodi and Kalpana (2004), Nageshwar et al. (1995) reported that application of sulphur @ 10 $\mathrm{kg} \mathrm{ha}{ }^{-1}$ through elemental sulphur resulted in significantly higher oil yields in sesame. Similar results were reported by Jadav et al. (2010).

Table 1. Effect of gypsum, lignite fly ash and pressmud on plant height in Sesamum indicum L. cv. VRI-1.

\begin{tabular}{|c|c|c|c|}
\hline \multirow{2}{*}{ Treatment details } & \multicolumn{3}{|c|}{ Plant height (cm) } \\
\hline & 25 DAS & 50 DAS & 75 DAS \\
\hline $\mathrm{T}_{1}-$ Control & 29.48 & 88.40 & 90.46 \\
\hline $\mathrm{T}_{2}-40 \mathrm{~kg} \mathrm{~S} \mathrm{ha}^{-1}$ as gypsum & 36.80 & 102.43 & 105.23 \\
\hline $\mathrm{T}_{3}-40 \mathrm{~kg} \mathrm{~S} \mathrm{ha}^{-1}$ as LFA & 34.60 & 98.46 & 100.46 \\
\hline $\mathrm{T}_{4}-40 \mathrm{~kg} \mathrm{~S} \mathrm{ha}^{-1}$ as pressmud & 31.96 & 94.50 & 96.43 \\
\hline $\mathrm{T}_{5}-20 \mathrm{~kg} \mathrm{~S} \mathrm{ha}^{-1}$ as gypsum $+20 \mathrm{~kg} \mathrm{Sha}^{-1}$ as LFA & 42.73 & 114.36 & 120.63 \\
\hline $\mathrm{T}_{6}-20 \mathrm{~kg} \mathrm{~S} \mathrm{ha}^{-1}$ as gypsum $+20 \mathrm{~kg} \mathrm{~S}^{-1}$ as PM & 38.93 & 106.43 & 110.43 \\
\hline $\mathrm{T}_{7}-20 \mathrm{~kg} \mathrm{Sha}^{-1}$ as LFA $+20 \mathrm{~kg} \mathrm{Sha}^{-1} \mathrm{PM}$ & 40.23 & 110.43 & 115.60 \\
\hline S.Ed. & 0.41 & 0.83 & 1.59 \\
\hline $\operatorname{CD}(p=0.05)$ & 0.91 & 1.85 & 3.46 \\
\hline
\end{tabular}


Table 2. Effect of gypsum, lignite fly ash and pressmud on seed yield and stover yield of Sesamum indicum L. $c v$. VRI-1.

\begin{tabular}{|c|c|c|}
\hline Treatment details & Seed yield $\left(\mathrm{kg} \mathrm{ha}^{-1}\right)$ & Stover yield $\left(\mathrm{kg} \mathrm{ha}^{-1}\right)$ \\
\hline $\mathrm{T}_{1}-$ Control & 385.60 & 751.92 \\
\hline $\mathrm{T}_{2}-40 \mathrm{~kg} \mathrm{~S} \mathrm{ha}^{-1}$ as gypsum & 551.53 & 1064.45 \\
\hline $\mathrm{T}_{3}-40 \mathrm{~kg} \mathrm{Sha}^{-1}$ as LFA & 473.50 & 918.59 \\
\hline $\mathrm{T}_{4}-40 \mathrm{~kg} \mathrm{~S} \mathrm{ha}^{-1}$ as pressmud & 410.33 & 792.07 \\
\hline $\mathrm{T}_{5}-20 \mathrm{~kg} \mathrm{~S} \mathrm{ha}^{-1}$ as gypsum $+20 \mathrm{~kg} \mathrm{Sha}^{-1}$ as LFA & 780.66 & 1522.28 \\
\hline $\mathrm{T}_{6}-20 \mathrm{~kg} \mathrm{Sha}^{-1}$ as gypsum $+20 \mathrm{~kg} \mathrm{Sha}^{-1}$ as PM & 615.63 & 1194.32 \\
\hline $\mathrm{T}_{7}-20 \mathrm{~kg} \mathrm{Sha}^{-1}$ as LFA $+20 \mathrm{~kg} \mathrm{Sha}^{-1} \mathrm{PM}$ & 673.33 & 1299.52 \\
\hline S.Ed. & 8.71 & 18.13 \\
\hline $\mathrm{CD}(p=0.05)$ & 18.98 & 39.50 \\
\hline
\end{tabular}

\section{Conclusion}

Based on the results of the field experiment, it is concluded that among the different treatments tried, application of $20 \mathrm{~kg} \mathrm{~S} \mathrm{ha}^{-1}$ as gypsum $+20 \mathrm{~kg} \mathrm{~S}^{-}$ 1 as LFA was superior in the performance of growth, yield attributes, yield and quality of sesamum.

The present study established the potentiality of lignite fly ash (an industrial waste, generated by the Neyveli Lignite Corporation, Ltd., Neyveli) as a source of sulphur for oil seed crops. Gypsum, lignite fly ash and pressmud can be combined and used as a source of sulphur to $\mathrm{S}$ deficient soils. The merits of both the sources of sulphur namely the former alkaline and the latter acidic in reaction are exploited for the advantage of preventing solid waste pollution.

\section{Conflict of interest statement}

Author declares that there is no conflict of interest.

\section{References}

Hegde, D.M., Sudhkara Babu, S.N., 2011. Nutrient management strategies for oil seed crops under Rainfed condition. Indian J. Fert. 7, 30-46.

Jadav, D. P., Padmani, D. R., Parmar, K. B., Babaria, N.B., 2010. Interaction effect of sulphur and potassium on yield and nutrients uptake by sesame. Asian J. Sci. 5, 144-147.
Kalpana, N.S., 2005. Influence of gypsum and lignite fly ash as sources of sulphur on the nutrient uptake and yield of sunflower. M.Sc. (Ag.) Thesis, Dept. of Soil Sci., Annamalai Univ., Annamalainagar.

Krishnaprabu, S., 2006. Agronomic strategies for yield maximization of sesame in rice fallow. Ph.D. Thesis, Department of Agronomy, Annamalai Univ., Annamalainagar.

Kuchanwar, O.D., Matte, D.B., Kene, 1997. Evaluation of graded does of fly ash and fertilizer on nutrient content and uptake of groundnut grown on vertisol. J. Soils Crops. 7, 1-3.

Maragatham, S., Govinthaswamy, M., Aruna Geetha, S., 2006. Influence of sulphur fertilization on seed and oil yield and sulphur uptake in sesame. Adv. Plant Sci. 19, 109-112.

Muthuraju, M., Ravi M.V., Siddaramappa, R., 2005. Enriched pressmud as source of nutrients and organic matter. Mysore J. Agric. Sci. 39, 134-137.

Muzaffer Sofi, A., Agarwal, S.B., Anoop Singh, 2004. Response of sunflower (Helianthus annus L.) to different levels of nitrogen and sulphur fertilization. Plant Arch. 4, 275-279.

Nageshwar Lal., Sarawgi, S.K., Tripathi, R.S., Bhambi, M.C., 1995. Effect of nitrogen, potassium and sulphur on seed yield, nutrient uptake, quality and economics of summer sesame (Sesamum indicum). Ind. J. Agron. 40, 33-335.

Poonkodi, P., Kalpana, N.S., 2004. Effect of lignite 
fly ash an industrial waste in boosting the growth and yield performance of sunflower. J. Pradusan Nirmulan. 1, 23-24.

Ramalingaswamy, K., Naidu, M.R., Mallikar Juna

Rao, T. K. V. V., 1996. Co-operat. Sugar. 27,
351-352.

Vishwakarma, S. K., Sharma, R. S., Karthik, S.K., 1998. Influence of varying sources and levels of sulphur on root characteristics and nodulation activity in soybean. J. Soils Crops. 8, 116-118.

\section{How to cite this article:}

Senthilkumar, N., 2018. Effect of sulphur sources on growth and yield of Sesamum indicum L. cv. VRI-1. Int. J. Curr. Res. Biosci. Plant Biol. 5(8), 58-62. doi: https://doi.org/10.20546/ijcrbp.2018.508.008 